\title{
SYYSRYPSIN TALVITUHOSIENIEN TORJUNTAKOKEITA KÄSITTELEMÄLLÄ KASVUSTOT FUNGISIIDEILLA
}

\author{
E. A. Jamalainen ja Matti Haavisto ${ }^{1}$ \\ Kasvitautien tutkimuslaitos, \\ Tikkurila
}

Saapunut 12. 10.1958.

Alustavissa syysrypsillä Tikkurilassa talvehtimiskaudella $1954-55$ tehdyissä kokeissa paransi myöhään syksyllä suoritettu kasvuston käsittely PCNB- (pentakloorinitrobentseeni-) valmisteella tehokkaasti talvehtimista ehkäisemällä talvituhosienien vahinkoja, jotka kokeissa olivat pääasiallisesti Typhula sp.- sienien aiheuttamia (1). Seuraavassa selostetaan vastaavia Kasvitautien tutkimuslaitoksen toimesta vv. 1955 - 1958 suoritettuja kokeita.

$\mathrm{K}$ o k e e t v. $1955-56$. Talvehtimiskausi $1955-56$ oli maassamme hyvin runsasluminen. Kun maa ei yleensä ollut syvään routautunut, esiintyi syysrypsissä ja muissa talvehtivissa kasveissa runsaasti talvituhosienien vaurioita (3); syysrypsissä niiden aiheuttajina olivat Typhula sp.- ja Sclerotinia sclerotiorum (Lib.) Bref.sienet.

Yhteistoiminnassa Kasviöljy Oy:n kanssa järjesti Kasvitautien tutkimuslaitos kokeita PCNB-valmisteilla eri tahoilla maata yksityisten viljelijöiden rypsipelloilla. Näissä kokeissa saatiin tulokset 15:sta koepaikasta (taul 1). Osassa kesällä 1955 kylvetyistä kokeista oli kasvusto turmeltunut talvehtimisen aikana niin pahoin, ettei satoa korjattu. Talvehtimisvaurioiden aiheuttajina olivat kokeissa talvituhosienet ja abioottisista syistä (vesi ja pakkanen) johtuvat vauriot (vrt. 2). Syystalven kasvustojen käsittelyt PCNB:llä olivat useissa kokeissa, parantaneet huomattavasti satoja. Kasvustojen tuhoutuminen talven aikana kokeissa, joissa talvituhosienistä oli tietoja, osoittivat ettei PCNB-käsittelyt olleet läheskään kokonaan ehkäisset sienten vaurioita.

Tikkurilassa v. 1955-56 järjestetyssä havaintoruutukokeessa (taul. 2) olivat talvehtimisvaurioiden aiheuttajina abioottiset tekijät ja talvituhosienet. Kokeen mukaan ei lokakuussa suoritettu PCNB-käsittely ollut tehonnut talvituhosieniin, kun taasen marraskuussa tapahtunut kasvuston käsittely paransi satoja, ehkäistessään sienien aiheuttamia vaurioita.

1) $†$ 20. 2. 1958 . 
Taul. 1. Kasviöljy Oy:n ja Kasvitautien tutkimuslaitoksen yhteiset syysrypsikokeet v. $1955-56$. Koeruudut $100 \mathrm{~m}^{2}$, kerranteita 3; pölytykset $20 \%$ :lla PCNB-valmisteilla, Botrilex tai Brassicol, kaksi kertaa à $25 \mathrm{~kg} / \mathrm{ha}$ (ensimmäinen käsittely useimmissa kokeissa lokakuussa ja toinen marraskuussa) tai kerran $50 \mathrm{~kg} / \mathrm{ha}$ (useimmissa kokeissa marraskuussa). Sienten vahingot Typhula sp:n ja Sclerotinia sclerotiorumin aiheuttamia.

Table 1. Tests with winter turnip rape made jointly by Kasviöljy Oy and the Department of Plant Pathology in 1955-56. Plots 100 sq.m., 3 replicates; dusting with $20 \%$ PCNB products Botrilex or Brassicol, twice, à $25 \mathrm{~kg} / \mathrm{ha}$ (the first treatment mostly in October, the second in November) or once, $50 \mathrm{~kg} / \mathrm{ha}$ (mostly in November). Damage from fungiduring winter caused by $T y p h$ u l sp. and $S$ clerot $i$ i a s clerot ior $u$ fungi.

Kokeiden sijainti

(sulkeissa kasvimaantieteellinen Tuhout. maakunta)

Site of test and geographical country talven
Käsittelemätön PCNB-valm. $2 \times 25 \mathrm{~kg} / \mathrm{ha}$ aikana aikana $\% \quad \mathrm{~kg} / \mathrm{ha} \quad \mathrm{sl} . \quad \% \quad \mathrm{~kg} / \mathrm{ha} \quad \mathrm{sl}$.

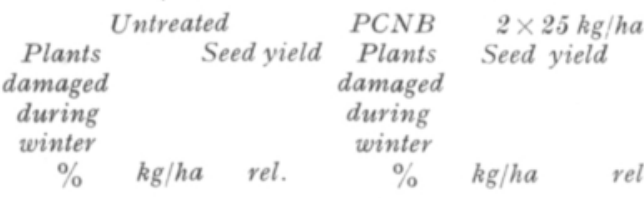

Espoo, Kilon kartano,

T. Nymalm (Nylandia)

Espoo, Nedra Lövkulla,

V. Weurlander (Nylandia)

Imatra, Immolan kartano,

Enso-Gutzeit (Savonia australis)

Jalasjärvi, Haapakallio,

A. Rinta-Kanto (Ostrobottnia australis)

Jyväskylä mlk, Harjula,

$\mathrm{S}$. Ilmoniemi (Tavastia borealis)

Jämsä, Eskola,

S. Veijo (Tavastia australis)

Karjaa, Prästgård,

B. Winberg (Regio aboensis)

koe 1 test 1

B. Winberg koe 2 test 2

Kemiö, Mask,

P. O. Söderholm (Regio aboensis)

Lammi, Ali-Halila,

E. Markkola (Tavastia australis)

Lapinjärvi, Mickels,

B. Tallberg (Nylandia)

Lapinlahti,

O. Jääskeläinen (Savonia borealis)

Mikkelin mlk., Pellosniemi,

T. Ernrooth (Savonia australis)

Ruotsinpyhtää, Pihtisalmi,

K. Pihtisalmi (Nylandia)

Sulkava, Hintsala,

E. Hintsanen (Ostrobottnia * australis)

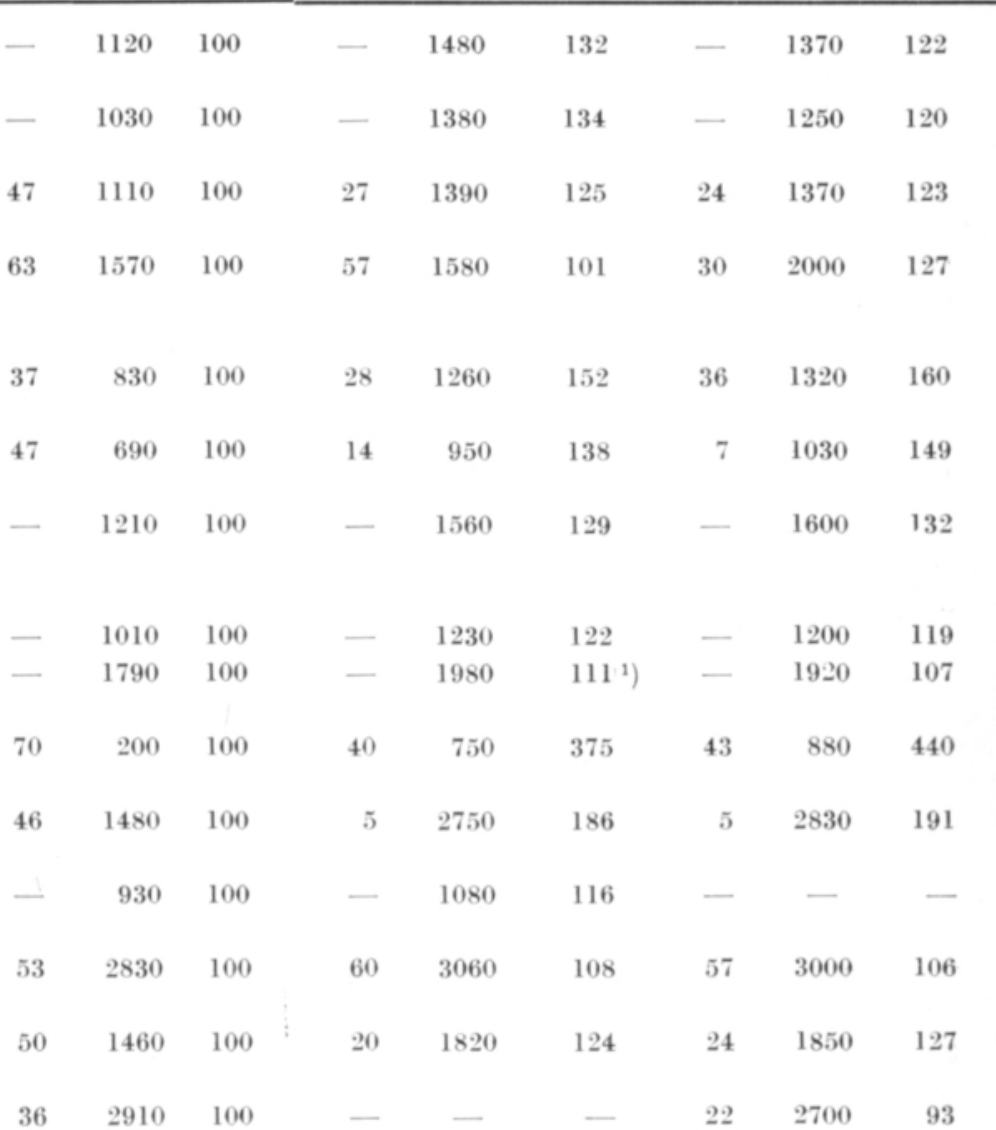

PCNB-valm. $1 \times 50 \mathrm{~kg} / \mathrm{ha}$

Tuhout. Siemensato

talven

aikana

$\%$ kg/ha sl.

$P C N B \quad 1 \times 50 \mathrm{~kg} / \mathrm{ha}$

Plants Seed yield

damaged

during

winter

$\% \quad \mathrm{~kg} / \mathrm{ha} \quad \mathrm{re}$.

1) Käsittely suoritettu vain kerran Treatment applied only once 
Taul. 2. Koe Tikkurilassa v. 1955-56. Havaintoruudut hietasavimaalla, Gruber syysrypsilajike, koeruudut $20 \mathrm{~m}^{2}$, yksi kerranne, kasvustojen käsittely Botrilex-valmisteella (20\% PCNB) yhdellä kertaa $25 \mathrm{~kg} / \mathrm{ha}$. Syksyllä kasvusto kaikissa koeruuduissa normaali ja yhtenäinen. Vauriot talven aikana abioottisten tekijöiden ja Typhula-sienten aiheuttamat.

Table 2. Test at Tikkurila in 1955-56. Observation plots on finesand clay, Gruber winter turnip rape variety, plots 20 sq.m., one replicate, treatment of stands with Botrilex (20 per cent PCNB) $25 \mathrm{~kg} / \mathrm{ha}$. In autumn the stands of all plots normal and even. Damages during winter caused by abiotic factors and T y $p$ h u l a sp. fungi.

\begin{tabular}{|c|c|c|c|}
\hline \multirow{2}{*}{$\begin{array}{l}\text { Käsittely } \\
\text { Treatment }\end{array}$} & \multirow{2}{*}{$\begin{array}{c}\text { Tiheys } \\
\text { keväällä } \\
0-10 \\
\text { Density } \\
\text { in spring } \\
0-10\end{array}$} & $\begin{array}{l}\text { Sier } \\
\mathrm{kg} / \mathrm{ha}\end{array}$ & sl. \\
\hline & & $\mathrm{kg} / \mathrm{ha}$ & rel. \\
\hline $\begin{array}{l}\text { Käsittelemätön } \ldots \ldots \ldots \ldots \ldots \ldots \ldots \ldots \ldots \ldots \\
\text { Untreated }\end{array}$ & 3 & 495 & 100 \\
\hline 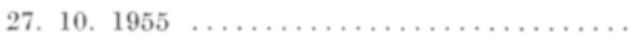 & 3 & 475 & 96 \\
\hline 3. 11. $1955 \quad \ldots \ldots \ldots \ldots \ldots \ldots \ldots \ldots \ldots \ldots \ldots$ & 4 & 600 & 121 \\
\hline 14. 11. $1955 \ldots \ldots \ldots \ldots \ldots \ldots \ldots \ldots \ldots \ldots$ & 4.5 & 865 & 175 \\
\hline 27. 10. \& 11. 11. $1955 \ldots \ldots \ldots \ldots \ldots \ldots$ & 4.5 & 795 & 161 \\
\hline 27. 10., 3. 11. \& 14. 11. $1955 \ldots \ldots \ldots \ldots \ldots$ & 4.5 & 845 & 171 \\
\hline
\end{tabular}

Kahdella koeasemalla ja Keski-Suomen liikkuvan koetoiminnan toimesta tehdyissä kokeissa (taul. 3) oli runsaasti talvituhosienien vaurioita. Käsittely PCNBvalmisteilla käyttäen joko $25 \mathrm{~kg}$ tai $50 \mathrm{~kg} 20 \%$ :sta PCNB-valmistetta hehtaarille ehkäisi tehokkaasti sienien tuhoja, josta oli seurauksena huomattavia siemensatojen lisäyksiä. Etelä-Pohjanmaan koeaseman kokeessa oli käsittelyn satoja parantava vaikutus epävarma. Huomattakoon, että toisessa Karjalan koeasemalla suoritetussa kokeessa paransi myös keväällä tehty käsittely jonkinverran satoa.

K o k e e t v. $1956-57$. Syksyllä 1956 oli järjestetty useita kymmeniä syysrypsin PCNB-käsittelykokeita eri puolilla maata, runsaimmin Lounais-Suomessa. Talvituhosienivaurioita ei näillä koealueilla esiintynyt, vaan olivat syysrypsin huonoon talvehtimiseen syynä pakkas- ja vesivauriot. Etelä-osissa Suomea tuli vesi sulana maahan, jossa se myöhemmin jäätyi yhtenäiseksi kattojääksi, ja näissä olosuhteissa kasvit tuhoutuivat.

$\mathrm{K}$ o k e e t v. $1957-58$. Talvehtimiskaudella oli yleensä runsaasti lunta kaikkialla Suomessa. Maa oli kuitenkin syystalvella hyvin routaantunut ja ilmeisesti sen vuoksi jäivät tuhosienivauriot melko vähäisiksi. Eteläosassa Suomea rypsi oli talvehtinutkin erittäin hyvin. Lumisilla seuduilla olivat abioottisista tekijöistä johtuvat vauriot runsaat.

Talven 1957-58 kokeissa ei edellä selostetuista syistä fungisiideilla saatu sanottavampia sadonlisäyksiin johtavia tuloksia. Yksi Tikkurilassa suoritetuista kokeista antoi kuitenkin viitteitä fungisiidien vaikutuksesta (taul. 4). Keväällä suoritettujen havaintojen mukaan olivat Typhula-sienet ja Sclerotinia sclerotiorum tässä kokeessa turmelleet jonkin verran kasvustoa talvehtimisen aikana. Tämä ilmenee myös kasvuston tiheysluvuista keväällä sekä satotuloksista sadonlisäyk- 
Taul. 3. Koeấsemien ja liikkuvan koetoiminnan kokeet v. $1955-56$.

Table 3. Tests at Experiment Stations and mobile field experiments in 1955-56.

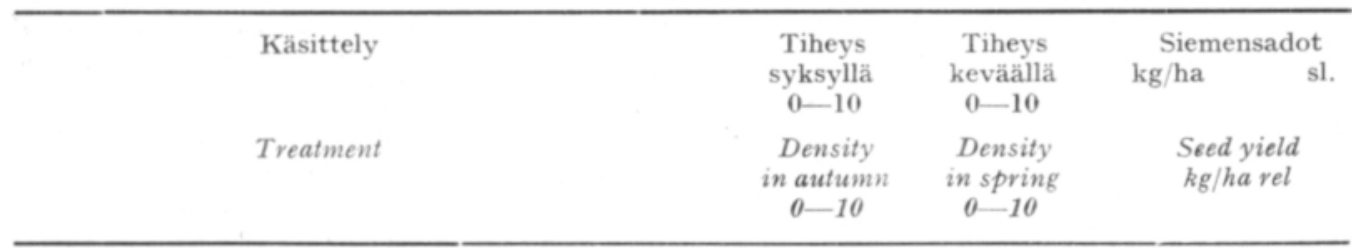

Karjalan koeasema, Anjala

Carelia Exp. Sta., Anjala (in the eastern part of South

Finland)

Käsittelemätön

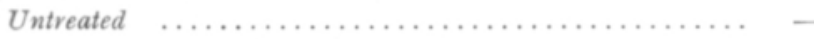

PCNB, Brassicol, $25 \mathrm{~kg} / \mathrm{ha}, 14.10 .1955 \ldots \ldots \ldots \ldots \ldots-$

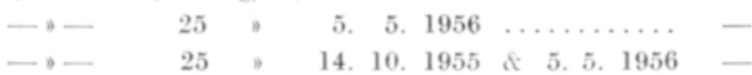

0.8

510

100

- $-\quad \begin{array}{rr}25 \\ -\end{array} \quad 25$

14. 10.1955 \& $5.5 .1956-$

4.7

830

163

Karjalan koeasema, Anjala

2.7

610

120

$4.7 \quad 880$

172

Carelia Exp. Sta., Anjala

Kăsittelemätön

1.0

330

100

Untreated

5.0

510

154

Etelä-Pohjanmaan koeasema, Ylistaro

South Ostrobothnia Exp. Sta., Ylistaro (in the western part of central Finland)

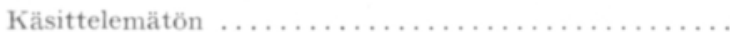

Untreated

PCNB, Botrilex, $25 \mathrm{~kg} / \mathrm{ha}, 19.11 .1955 \ldots \ldots \ldots \ldots$ -

- 50, 19. 11. $1955 \ldots \ldots \ldots \ldots$

Keski-Suomen liikkuva koetoiminta

Mobile field experiments in Central Finland

Laukaa, Varjolan tila

Laukaa, Varjola farm (in the western part of Central

Finland)

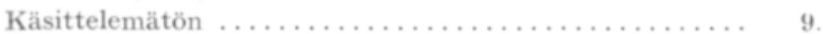

Untreated

PCNB, Botrilex, $25 \mathrm{~kg} / \mathrm{ha}, 19.11 .1955 \ldots \ldots \ldots \ldots .9 .1$

$$
-50 \text { - } 50
$$

19. 11. 1955

8.8

Laukaa, Harjun tila

$5.8 \quad 1690$

Laukaa, Harju farm

Käsittelemätön

Untreated

PCNB, Botrilex, $25 \mathrm{~kg} / \mathrm{ha}, 19.11 .1955 \ldots \ldots \ldots \ldots .7 .5$

7.3

5.0

1080

senä. Kokeen perusteella PCNB-käsittely marraskuussa käyttäen $100 \mathrm{~kg} / \mathrm{halle}$ paransi selvästi satoa, silloin kun vähäisemmät määrät jäivät teholtaan heikoiksi. PMA- (fenyylimerkuriasetaatti-) käsittelyn vaikutus sekä loka- että marraskuussa oli samaa suuruusluokkaa kuin $20 \%$ :nen PCNB-valmiste annettuna $100 \mathrm{~kg}$ hehtaarille. Verdasan-valmisteessa tuli fenyylimerkuriasetaattia $425 \mathrm{~g}$ hehtaarille. 
Taul. 4. Koe Tikkurilassa v, 1957-58. Hietasavimaalla, Gruber-syysrypsilajike, koeruudut $21.6 \mathrm{~m}^{2}$, kerranteita 4, kylvö 20. 7. 1957. Syksyllä kasvusto kaikissa koeruuduissa normaali ja yhtenäinen. Sienivauriot talven aikana Typhula sp.-sienien ja Sclerotinia sclerotiorumin aiheuttamat.

Table 4. Test at Tikkurila in 1957-58. On finesand clay, Gruber winter turnip rape variety, plots 21.6 sq.m., four replicates, sowing July 20. In autumn the stands in all plots normal and uniform. Damages from fungi during winter caused by $T$ y $p$ h ula sp. and Sclerotinia sclerotiorum.

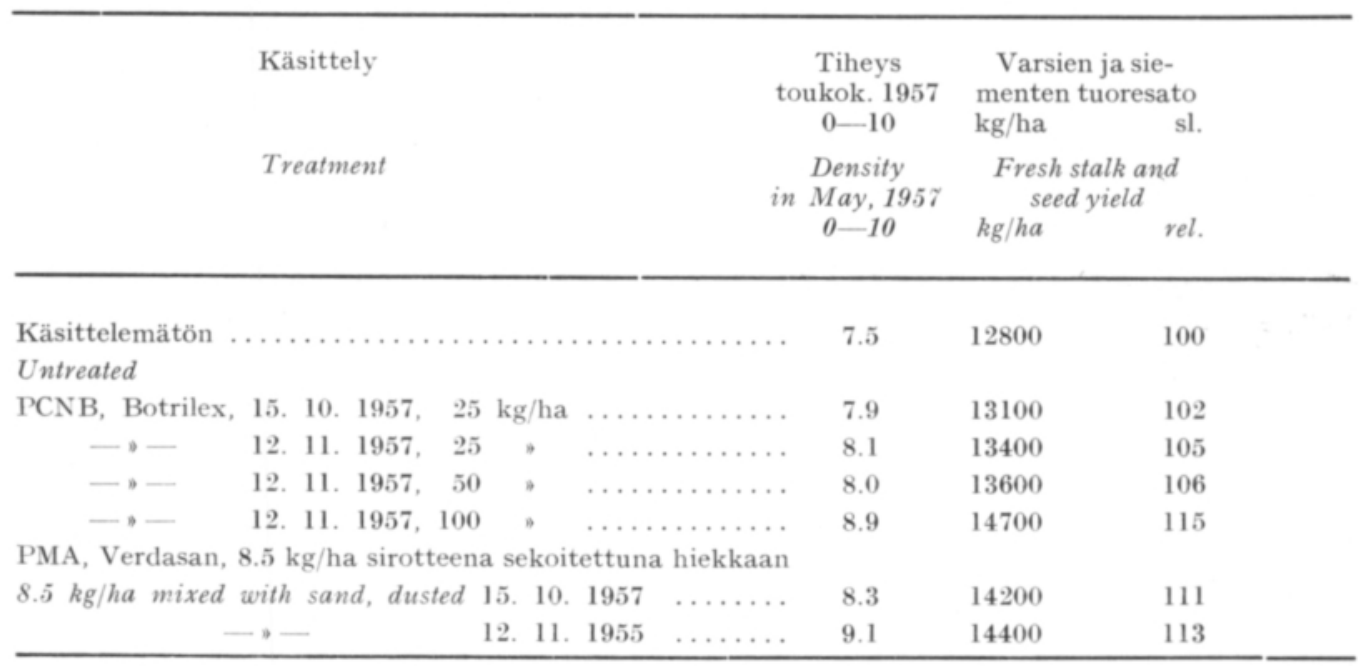

\section{Talvituhosienitorjunta-aineiden käytöstä syysrypsin viljelyssä}

Edellä esitetyt kokeet osoittivat, että silloin kun olosuhteet ovat eduliiset talvituhosienien vahingoille, johtavat syksyllä suoritetut syysrypsikasvustojen käsittelyt fungisiideilla huomattaviin sadonlisäyksiin ehkäistessään talvituhosienien vaurioita. Kun syysrypsin viljely keski-, itä- ja pohjois-Suomessa usein täysin epäonnistuu talvehtimisen aikana abioottisista syistä johtuvien vaurioiden vuoksi (2), ei näissä osissa maatamme kasvustojen syystalvikäsittelyt fungisiideilla vastaa tarkoitustaan, vaikka niillä voidaankin estää talvituhosienien vaurioita. Etelä- ja länsi-osissa Suomea, jossa edellä mainitut vauriot eivät ole ratkaisevana esteenä syysrypsin viljelylle, kannattanee ryhtyä käyttämään kemiallisia aineita sellaisissa kasvupaikoissa, joissa talvituhosienien vaurioita esiintyy vahingollisena.

\section{Yhteenveto}

Talvehtimiskaudella $1955-56$, jolloin esiintyi runsaasti talvituhosienten (Typhuta sp. ja Sclerotinia sclerotiorum) vaurioita, saatiin kasvustojen käsittelyllä syystalvella PCNB-valmisteilla useimmissa kokeissa (yhteensä 21 koetta) siemensadon lisäyksiä käytettäessä $20 \%$ :sta PCNB- (pentakloorinitrobentseeni-) valmistetta 25 tai $50 \mathrm{~kg} /$ halle. Kolmessa kokeessa oli siemensadon lisäys yli $100 \%$ (1060$550 \mathrm{~kg} / \mathrm{ha})$, viidessä $100 \%$ - yli $50 \%(1350-370 \mathrm{~kg} / \mathrm{ha})$, kahdeksassa $50 \%$ yli $20 \%(430-220 \mathrm{~kg} / \mathrm{ha})$ ja viidessä alle $20 \%(230-0 \mathrm{~kg} / \mathrm{ha})$. 
Lukuisissa v. 1956-57 etelä-osissa maata suoritetuissa vastaavissa kokeissa ei esiintynyt talvituhosieniä; silloin olivat abioottiset tekijät syynä syysrypsin huonoon talvehtimiseen.

V. 1957-58 suoritetuissa kokeissa ei esiintynyt paljoa talvituhosienivaurioita. Yhdessä kokeessa $100 \mathrm{~kg} / \mathrm{ha} 20 \%$ :sta PCNB-valmistetta marraskuussa annettuna tehosi talvituhosieniin samoin kuin $8.5 \mathrm{~kg}$ halle PMA-valmistetta (fenyylimerkuriasetaattia $425 \mathrm{~g} /$ halle) annettuna loka- tai marraskuussa.

Myöhäisempi, etelä-Suomessa marraskuussa tapahtuva kasvustojen käsittely PCNB:lla antoi varmemman torjuntatuloksen kuin aikaisempi, lokakuussa suoritettu.

\title{
KIRJALLISUUTTA
}

(1) Haavisto, M., Jamalainen, E. A. \& Ylimäki, A. 1956. Observations on the effect of pentachlornitrobenzene on the low-temperature fungus pathogens in winter turnip rape. Selostus: Havaintoja pentaklornitrobentseenin vaikutuksesta syysrypsin talvituhosieniin. Valt. maatal.koet. julk. (Publ. Finnish Sta. Agric. Res.) 148: 62 - 67.

(2) JAmalainen, E. A. 1958. Kasvien talvehtimisesta ja sen parantamismahdollisuuksista. Kasvinsuoj.seur. julk. 13: 1-40. - Om växternas övervintring. Sv. lantbr.sällsk. i Finland förb. Ser. 13, 22: 1-41. Helsinki.

(3) - 1958. Experiments on the use of some chloronitrobenzene and organic mercury compounds for the control of low-temperature parasitic fungi in winter cereals. Selostus: Syysviljojen talvituhosienien torjuntakokeita eräillä kloorinitrobentseeni- ja orgaanisilla elohopeavalmisteilla. Maat.tiet. aikak. (J. Sci. Agric. Soc. Finland) 30: 251-263

S U M M A R Y :

TESTS ON THE CONTROL OF LOW-TEMPERATURE PARASITIC FUNGI IN WINTER TURNIP RAPE BY TREATMENT OF STANDS WITH FUNGICIDES

\author{
E. A. Jamalainen and Matri Haavisto \\ Department of Plant Pathology, Agricultural Research Centre, \\ Tikkurila
}

In preliminary tests with winter turnip rape (Brassica campestris var. oleifera f. biennis) at the Department of Plant Pathology in $1954-1955$, treatment of the stands with a PCNB (pentacholronitrobenzene) compound carried out in the autumn before snow-fall improved the overwintering by reducing the damage caused by low-temperature parasitic fungi, in particular the Typhula sp. (1).

Tests in $1955-56$. The winter $1955-56$ was very snowy though the soil was not frozen deep in general. The winter turnip rape was greatly damaged by low-temperature parasitic fungi, i.e. the Typhula sp. fungi and the Sclerotinia sclerotiorum (Lib.) Bref.

The Department of Plant Pathology arranged with Kasviöljy Oy. (an industrial concern which prepares oil from winter turnip rape) joint tests with PCNB products in different parts of the country in the winter turnip rape fields belonging to different farmers. The results of 15 tests (Table 1) were received. The damage was caused by low-temperature parasitic fungi and by abiotic factors (cold and water). Treatments of stads with $20 \% \mathrm{PCNB}$ in the autumn had noticeably increased the seed yields in many tests. 
In an observation plot test in Tikkurila in 1955-56 (Table 2) the losses during overwintering were caused by abiotic factors as well as low-temperature parasitic fungi. PCNB reatment in October was not effective against the fungi, but treatment carried out in November prevented the damages caused by the fungi and increased the yields.

In the other tests (Table 3) treatment of winter turnip rape stands with PCNB, using $25 \mathrm{~kg}$ or $50 \mathrm{~kg} 20 \%$ PCNB per hectare, effectively prevented damages from low-temperature pathogens resulting in considerable increases in the yields. In the test at the South Ostrobothnia Experiment Station the yield increasing effect proved uncertain. It should be noted that in one test at the Carelian Experiment Station a treatment carried out in the spring also improved the yield to some extent.

In tests with winter turnip rape in 1955-56 the seed yields increased in most tests (in total 21 tests) with the use of a $20 \%$ PCNB preparation, 25 or $50 \mathrm{~kg}$ per hectare. In three of the tests the increase in seed yields was over $100 \%(1060-550 \mathrm{~kg} / \mathrm{ha})$, in five tests $100 \%$ over $50 \%(1350-370 \mathrm{~kg} / \mathrm{ha})$, in eight tests $50 \%$ - over $20 \%(430-220 \mathrm{~kg} / \mathrm{ha})$ and in five tests below $20 \%(230-0 \mathrm{~kg} / \mathrm{ha})$.

Tests in 1956-57. In the autumn of 1956 scores of PCNB treatment tests with winter turnip rape were made in different parts of the country, mostly in S-W Finland. There were practically no injuries caused by low-temperature parasitic fungi in these cases the poor overwintering of the winter turnip rape being the result of injuries from cold and water.

Tests in $1957-58$. In the winter there was a great deal of snow practically everywhere in Finland. In the late autumn the ground froze to a considerable depth which may explain why the injuries from low-temperature parasitic fungi in winter tirnip rape remained rather small. In southern Finland winter turnip rape overwintered very well.

For reasons related above no special improvements in yields through the use of fungicides were achieved in the experiments of the winter 1957-58. One of the tests in Tikkurila did, however, give some indication of the effects of fungicides (Table 4). According to the test a treatment with BCNB in November, $100 \mathrm{~kg}$ per hectare, distinctly resulted in an improvement in the yield while smaller quantities that were used remained ineffective. Treatment with PMA (phenylmercuryacetate) in October and November was similar in effect as the $20 \%$ PCNB preparation administred in the quantity $100 \mathrm{~kg}$ per hectare. The amount of phenylmercuryacetate in the Verdasan preparation amounted to $425 \mathrm{~g}$ per hectare.

The use of fungicides in the cultivation of winter turnip rape. If conditions for the development of low-temperature parasitic fungi are favourable, treatments of stads with fungicides in the autumn result in considerable increases in the yields by controlling the losses caused by the fungi. As winter turnip rape is frequently a failure in central, eastern and northern Finland owing to injuries from abiotic factors (2), treatment of stands of winter turnip rape in these parts of the country scarcely meets the case although it is possible in this way to control the losses from low-temperature pathogens. In southern and western parts of the country, where losses caused by water do not form a decisive obstacle to the cultivation of winter turnip rape, it may prove profitable to start using the fungicides in question in such places where injuries from low-temperature parasitic fungi have been observed. 